DOI: https://doi.org/10.34069/AI/2021.44.08.18 How to Cite:

Pryimachenko, D., Lipynskyi, V., Maslova, A., Voloshina, S., \& Varhuliak, O. (2021). Accessibility of facilities and services for people with disabilities in the paradigm of law. Amazonia Investiga, 10(44), 188-197. https://doi.org/10.34069/AI/2021.44.08.18

\title{
Accessibility of facilities and services for people with disabilities in the paradigm of law
}

\section{Доступність об’єктів і послуг для осіб з інвалідністю в парадигмі права}

Received: July 20, 2021

\section{Abstract}

The authors of the article touch on the major topic of ensuring access of persons with disabilities to facilities and services, which is an indicator of guaranteeing the rights and freedoms of such citizens and ultimately determines the quality of life of such people. The article analyzes the current Ukrainian legislation, as well as international legal acts governing relations regarding access of persons with disabilities to the general infrastructure. The methodology of the article includes methods of analysis, synthesis, formal-legal and comparative-legal methods. The essence of the right of persons with disabilities to access facilities and services is the legally guaranteed possibility of these persons to freely use all facilities and services without any barriers, including through the adaptation of the latter or their special design. The authors of the article thoroughly researched the concept and content of the right of persons with disabilities to access facilities and services. Finally, the authors concluded that the current domestic legislation, although ensuring the minimum level of rights of
Accepted: September 9, 2021

Written by:

Dmytro Pryimachenko ${ }^{71}$ https://orcid.org/0000-0001-8504-2450

Vladyslav Lipynskyi ${ }^{72}$ https://orcid.org/0000-0002-4373-3330

Anna Maslova ${ }^{73}$ https://orcid.org/0000-0002-4404-9792

Svitlana Voloshina ${ }^{74}$ https://orcid.org/0000-0001-7148-6923

Olena Varhuliak ${ }^{75}$

https://orcid.org/0000-0003-2097-4681

\footnotetext{
${ }^{71}$ Doctor of Law, Professor, Vice-Rector of the University of Customs and Finance, Ukraine.

${ }^{72}$ Doctor of Law, Associate Professor, Head of the Educational and Scientific Institute of law and international legal relations of the University of Customs and Finance, Ukraine.

${ }^{73}$ Doctor of Law, Associate Professor of the Department of Administrative and Customs Law, University of Customs and Finance, Ukraine.

${ }^{74}$ Ph.D., Associate Professor at the Department of Labour and Social Security Law of the National University "Odesa Law Academy", Ukraine.

${ }^{75} \mathrm{Ph} . \mathrm{D}$. candidate of the University of Customs and Finance, Ukraine.
} 


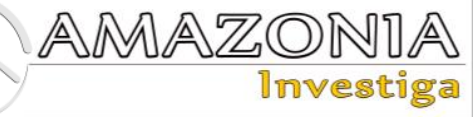

persons with disabilities in the study area but needs to be improved taking into account the positive experience of European countries and following the United Nations Convention on the Rights of Persons with Disabilities.

Keywords: human rights, persons with disabilities, accessibility of facilities and services, inclusiveness, low mobility groups.

здійснено глибокий аналіз чинного законодавства України i міжнародних нормативно-правових актів, присвячених правам осіб 3 інвалідністю. Автори статті зробили висновок, що чинне вітчизняне законодавство, хоч i забезпечує на мінімальному рівні права осіб з інвалідністю у досліджуваній сфері, проте потребує удосконалення 3 урахуванням позитивного досвіду Європейських країн і у відповідності до Конвенції ООН про права осіб 3 інвалідністю.

Ключові слова: права людини, особи 3 інвалідністю, доступність об'єктів і послуг, інклюзивність, маломобільні групи населення.

\section{Introduction}

The right of persons with disabilities to access facilities and services is a complex, multifaceted category, with both general and specific properties. It is concretized in many norms and provisions of legislative acts, as it is inextricably linked with other human rights.

The lack of thorough research in this area has the consequence of a lack of clear understanding of the nature of the right of persons with disabilities to access facilities and services, including the administrative and civil law of its implementation.

Thus, the right to access facilities and services directly to persons with disabilities is guaranteed by the United Nations Convention on the Rights of Persons with Disabilities (2006) (the Convention). The subjects of the studied law are persons with disabilities, regardless of affiliation to a particular state. At the same time, each state, depending on the level of its development, provides persons with disabilities with opportunities to exercise the relevant right.

People with disabilities who need special / assistive devices or technologies to move or orient themselves can be grouped into the following groups:

- $\quad$ persons with musculoskeletal disorders;
- $\quad$ persons with visual impairment, and;
- $\quad$ persons with hearing impairment.

Considering the right to the accessibility of facilities and services, it should be borne in mind, that the need for accessibility of the external environment is present in a much larger number of people than people with disabilities. Under certain circumstances, the elderly, mothers with baby carriages, people with suitcases, temporarily ill people who use sticks or crutches, people with large food packages, etc. need accessibility.

Thus, the authors of this study aimed to thoroughly investigate all aspects of ensuring the right of persons with disabilities to access facilities and services and to carefully analyze domestic and international legislation in this area.

\section{Theoretical Framework or Literature Review}

The authors both in Ukraine and abroad pay attention to the protection of the rights of persons with special needs.

Thus, David Allen Larson (2014) in his article «Access to Justice for Persons with Disabilities: An Emerging Strategy». The article examines some aspects of the use of new technologies in the field of legal protection of the rights of persons with disabilities. In addition, the author makes his own suggestions about additional ways to use the technology.

Moreover, Gloria L. Krahn, Deborah Klein Walker and Rosaly Correa-De-Araujo, (2015) in their article «Persons With Disabilities as an Unrecognized Health Disparity Population», show that the issue of ensuring the rights of people with disabilities is very important, because, for example, in the United States, people with severe disabilities make up more than $12 \%$ of the total population. The authors study the current state of ensuring the rights of people with disabilities. In addition, they offer 
their own vision of methods of overcoming the inequality of these categories of persons with other citizens. Rather, they include improving access to health care, building the capacity of the health workforce, including people with disabilities in public health programs, and increasing emergency preparedness.

Besides, Andrea Broderick (2015), in her book «The Long and Winding Road to Equality and Inclusion for Persons with Disabilities», examines several aspects of the equality and nondiscrimination norms in the UN Convention on the Rights of Persons with Disabilities (2006) (CRPD). The book thoroughly analyzes the norms of the CRPD. The author concludes that the provisions of the Convention are sufficient to ensure a decent level of rights for persons with disabilities, but much remains to be done in law enforcement.

What is more, Andrea Broderick and Lisa Waddington (2016) presented a report on the status of implementation of regulations on the protection of the rights of persons with disabilities. The report examines the state of fulfillment of the responsibilities of EU member states in the field of protection of people from discrimination on the grounds of disability.

Finally, Andrea Broderick and Delia Ferri (2019) in their textbook on international and European disability law and policy, analyze the interaction between different legal systems and sources. The book contains detailed information on various aspects of the legal provision of the rights of persons with disabilities. It is based on the analysis of CRPD standards, supplemented by interesting cases from practical activities.

Despite the large number of scientific developments on the issue of ensuring the rights of persons with disabilities, some aspects of the relevant relations remain poorly covered. In particular, the issues of accessibility of facilities and services for people with disabilities need more thorough analysis.

\section{Methodology}

The basic methods used by the authors in preparing this study include methods of analysis and synthesis.

So, analysis and synthesis are two diametrically opposite methods of scientific knowledge, which are mutually complementary and, thanks to their joint use, allow to achieve the depth and completeness of research, as well as to confirm the reliability of the data obtained.

Analysis is the division of the model of an object into its constituent parts, properties, signs, relations and their subsequent study individually or in various combinations. The analysis of state and legal phenomena, coupled with formalization, allows us to fix the constituent elements, find out the nature of the relationship between them, systematize, abstracting from secondary properties and signs.

Thus, the method of analysis allowed us to clarify the essence of the concept of "accessibility" of persons with disabilities to infrastructure and services, to establish its constituent elements, including physical accessibility (absence of physical barriers), for example - transport accessibility, accessibility entrance to government and other buildings, etc., and actual accessibility (availability of information, services, etc.), for example - information accessibility, accessibility to justice.

Synthesis, as noted above, is the process of cognition, the opposite of analysis, which consists in combining knowledge about individual parts, properties, relations of a certain object into a certain system based on the results of their previous analytical research. The result of such a synthesis can be knowledge about the interaction of parts or properties of the object under study, the establishment of causal relationships between its individual components, finding the dependence of the function of each part of the object on the function of the object as a whole.

Moreover, the method of synthesis allowed the authors of the study to formulate clear ways to overcome the problems associated with the accessibility of citizens with disability to facilities and services, and thus ensure the protection of their constitutional rights to normal life. The main goal of the state and the public in this aspect is the creation of an inclusive society, in particular, ensuring universal design, introduction of modifications and adaptations of space, curricula, public services taking into account the needs of people with disabilities.

Regarding such traditional methods for legal research as the formal-logical and comparativelegal method, they helped to formulate proposals for improving the current legislation in the study area, taking into account the positive experience of foreign countries in ensuring the rights of persons with disabilities, as well as thoroughly 


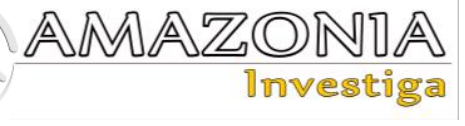

analyze domestic legislation. the subject of compliance of its provisions with international regulations in the field under study - in particular, the Convention on the Rights of Persons with Disabilities.

\section{Results and Discussion}

At the international level, the basic document containing guarantees for the rights of persons with disabilities is the Convention (United Nations, 2006). In particular, Article $9 \S 1$ of the Convention guarantees persons with disabilities equal access to facilities and services.

Within the meaning of the Convention (United Nations, 2006), these facilities and services include buildings, roads, transport, and other internal and external facilities, including schools, houses, medical facilities and workplaces, information, communication, and other services, including electronic services and emergency services

The cited provision of the Convention clearly outlines the list of facilities and services to which access should be provided for persons with disabilities, as well as obliges the state to take appropriate measures. Among other things, we consider it necessary to emphasize the territorial affiliation of certain facilities and services, in particular, at the village and city levels. Thus, the legislator at the level of an international legal act has established a kind of prohibition of discrimination against persons with disabilities at the place of residence.

It should be noted that the right of persons with disabilities to access facilities and services is not enshrined in the Constitution of Ukraine (Law No. 254к/96-BP, 1996), but certain aspects are sanctified in Articles 21, 34, 36, 38, 43, 50, 53, 57,59 of the Constitution.

Concerning national legislation, according to Article 4 of the Law of Ukraine, "On Fundamentals of Social Protection of Persons with Disabilities in Ukraine" (Law No. 875-XII, 1991), the state's activities to persons with disabilities are manifested in the creation of legal, economic, political, social, psychological, etc.

The content of this article shows more detailed than the Convention (United Nations, 2006) powers of the state to ensure access to facilities and services for persons with disabilities, as it defines the list of activities of the state, namely: "creation of legal, economic, political, social, psychological and other conditions" and "identifying, removing obstacles and barriers to the provision of rights and meeting needs, including access to...". Moreover, Article 4 of the Law No. 875-XII (1991), covers all spheres of life of persons with disabilities, thereby obliging the state to ensure unimpeded access to them.

Remarkably, the legislator uses the concept of "barriers" because their presence makes accessibility impossible. Today, in the sphere of life of people with disabilities, the following barriers to integration into society are still encountered, along with others:

- mental barriers, which are probably the most common social phenomenon. They consist in the specific attitude of people to people with disabilities, misunderstanding of their problems and, thus, cause the urgent need to eliminate them;

- physical barriers, which are the second most negative phenomenon. This is a lack of architectural and transport accessibility, which is the main obstacle to access for people with disabilities to education, work, culture, sports, information, tourism, etc. When arranging the street environment adjacent to the building, entrances, and interior space (corridors, rooms, classrooms, halls, etc.), it is necessary to take into account the possibility and features of using compensatory and aids used by people with disabilities, the degree of damage to such people and their nosology. For example, a person moving in a wheelchair needs more room to maneuver and no thresholds, curbs, stairs, steps, steep slopes, etc. on the roads. Some tactile and contrast landmarks, visual accompaniment of visual announcements, Braille markings, etc. are necessary for safe movement and better memorization of routes for the visually impaired. For people with hearing impairments, it is essential not only to have communication technologies available visual information (including the danger in the bathrooms), but also the presence of staff trained in the basics of sign language (Azin, Baida, Grybalsky, \& Krasyukova-Enns, 2013). The concept of "available transport" can be considered, first, as the accessibility of the vehicle itself; secondly, as a transport infrastructure arranged following current standards and needs of people with disabilities and low mobility groups (parking spaces, entrances to terminals, elevators and escalators, telephone booths, trade and catering 
establishments on the territory of stations; universal toilets; information in appropriate formats, etc.). Thus, "transport accessibility" is the opportunity given to people with physical, sensory, or cognitive impairments to remain mobile and use independently under all conditions all services and vehicles that are open and provided to the entire population (Azin, Baida, Grybalsky, \& Krasyukova-Enns, 2013).

- information barriers, which in most cases affect people with visual impairments (no duplication of visual information by audio information), hearing (no duplication of visual information by audio data), mental retardation, and mental disorders (lack of data in simplified language). These barriers are caused by the non-use of existing information formats that take into account the needs of people with disabilities with visual, hearing, mental disorders, and speech retardation.

Access to information and means of communication is an assential aspect of ensuring active participation in society and a condition for the realization of rights for all people. Access to information includes the right to seek, receive and impart information and ideas relating to human rights, civil, social, political and economic issues.

The issue of ensuring information accessibility concerns all aspects of life of people with disabilities: accessibility of information in transport, when traveling at railway stations and airports, in catering establishments, hospitals, pharmacies; during the educational process - the release of textbooks in Braille or on electronic media; in television programs using sign language; theatrical performances and works of art, materials for voting during the election process, etc.

Information accessibility for people with disabilities should take into account the degree and type of functional impairment. How to ensure, for example, access to information and communication for deaf people? The key in this matter is the observance of the principles of accessibility and recognition of sign language, culture, and identity of the deaf.

According to the World Federation of the Deaf, more than $40 \%$ of countries do not broadcast news and programs about current events in sign language, only $22 \%$ of countries provide subtitling services. There are only a few countries, one of them, Thailand, that provides the issuance of government documents in the sign language of the country (United Nations, 2010).

Ensuring information accessibility is the most serious condition for the integration of the blind and partially sighted into society. It can be represented in different ways: Braille, large print, audio, electronic means, tactile.

ATMs have become an integral part of modern life. But are the needs of blind people who have the right to use the bank's services on an equal footing with others taken into account? Most often - no. The proliferation of inaccessible ATMs and the use of credit cards, which are inaccessible to blind and partially sighted users, discriminate against this group of people and lead to serious privacy problems because they have to rely on the help of others (United Nations, 2010).

Here is another example: the use of PDF files, which are often inaccessible to blind people. Some organizations and companies use scanned files that are completely inaccessible to them. This is another indication that the individual needs of such users are often not taken into account. Today, many information services are provided through websites. They are increasingly becoming the only service option for many people. Unfortunately, not all service providers (hotels, shops, libraries, banks, hospitals, etc.) provide access to their websites. It is especially necessary to give people with disabilities of various nosologies information during emergencies. If the hazard information is not presented in accessible formats, it poses a threat to the lives of many people.

Many people with disabilities use assistive technologies, which include several technological solutions - from simple devices (such as hearing aids) to complex text-to-speech programs used by the blind to work on a computer, use software applications, access web pages, etc. Assistive technologies provide people with disabilities with a tandard interface with ways of interacting and output formats that meet their needs.

Accessibility products (or assistive technologies) are special hardware and software that significantly increase the accessibility of computers for people with disabilities.

In particular:

- alternative keyboards of different sizes with different keyboard layouts and angles; 


\section{AMAZONDA \\ ปnvestig.}

- electronic pointing devices that allow you to control the movement of the pointer on the screen with ultrasound, infrared rays, eye movements, signals of nerve endings, and brain waves;

- control devices by breathing and swallowing - use one of the types of access using switches. In the standard configuration, a saliva extraction device is attached to the switch. The user activates the switch with his breath;

- joysticks - connect to the port for the "mouse" and are used to control the pointer on the screen;

- the magnifier works like glass, which enlarges the image and increases its sharpness;

- institutional barriers to the legal regulation of various aspects of the life of persons with disabilities: either the needs of persons with disabilities are not taken into account, or are not fully taken into account or without taking into account the interests of this category of persons, or contradict their needs, or certain legal requirements are not implemented in practice, and;

- financial, due to the financial inability of the vast majority of people with disabilities to meet even vital needs due to poverty and impoverishment.

An idea of the existing barriers makes it possible to classify accessibility by type, namely:

- $\quad$ architectural (accessibility of buildings);

- transport and transport infrastructure facilities;

- informational, and

- financial (sufficient financial security of persons with disabilities and economic justification of the value of goods and services, consumers of which are the specified category of the population).

Thus, accessible is one that is freely accessible in the context of architecture, finance, perception, and understanding, etc.

Hence, accessibility of facilities and services for people with disabilities means the property of the relevant facilities and services, which allows people in this category to use them freely without any barriers, including through adaptation or special design.

This applies to various aspects:

1) proper legislative regulation of the issue of employment of persons with disabilities, taking into account all their needs and legitimate interests;

2) acceptance of people with disabilities as full participants in labor relations;

3) ensuring the architectural and transport accessibility of the environment, and;

4) use of information in accessible formats for its perception by persons with disabilities with visual, hearing, mental disorders, and mental retardation ...

Among other things, accessibility varies depending on the category of people targeted. Thus, for people with musculoskeletal disorders, it is crucial to have no stairs or a standard elevator, while for people with hearing impairments, it is necessary to be able to communicate in sign language, for example, when buying drugs at the pharmacy.

Along with the concept of accessibility, you can often hear the concept of inclusiveness.

According to Article 1 of the Law of Ukraine "On Education" (Law No. 145-VIII, 2017):

inclusive education - a system of educational services guaranteed by the state, based on the principles of non-discrimination, taking into account human diversity, effective involvement, and inclusion in the educational process of all its participants (paragraph 12 of the first part of Article 1).

Inclusiveness of buildings and structures - a set of architectural and planning, engineering, ergonomic, structural, and organizational measures to ensure the accessibility of buildings and structures in which every person, regardless of age, gender, disability, functional impairment, level of communication, or circumstances, can feel safe and comfortable without assistance and to the best of your ability.

The analysis of the above definitions gives grounds to conclude that the concepts of "accessibility" and "inclusiveness" are identical because they indicate the conditions under which persons with disabilities live in a society on an equal footing with other people, regardless of their disabilities.

The above gives grounds to single out the following characteristic features of the right of persons with disabilities to access facilities and services:

1) the subject of the right is a person with a disability. The right to access facilities and 
services is also used by other low-mobility groups (hereinafter - LMG), which will be discussed below;

2) promotes equality of persons with disabilities in society;

3) applies to all spheres of life of persons with disabilities without exception;

4) may not be limited depending on the territorial affiliation of a person with a disability, and;

$5)$ is provided by the state by creating legal, economic, political, social, psychological, and other conditions by means of identifying, removing obstacles and barriers in all spheres of life of persons with disabilities.

Kondratenko (2019), in his thesis, noted that ensuring the accessibility of persons with persistent disorders of the body to the infrastructure in the social sphere is based on the following principles:

creation of a barrier-free environment taking into account nosological forms of disability;

reaching a state-public consensus on ways and means of adaptation to the physical and information environment;

selection of optimal engineering and architectural solutions, application of universal design;

harmonization of domestic legislation with international law;

scientific, technical, and economic feasibility, adaptability of decisions, and;

public and public control at all stages of the construction rationing and standardization procedure.

In Black's Legal Dictionary (Black, 1968), access is defined as a way to approach or enter; the right or opportunity to reach, use or visit. As we can see, the meaning refers more to the objects of the material world. At the same time, for example, the information sphere was left out of consideration.

It should be remarked, that Ovcharenko (2008) (in his monograph on access to justice) notes that access to justice is a state of organization of the judiciary and jurisdictional activity of the court in a democratic society, which satisfies the latter's need to resolve legally significant cases and meets the requirements of international law. Access to justice is ensured by the optimal construction of the judicial system, which provides for the possibility of at least double review of the decision of the court of the first instance, is territorially close to the population, and a system of procedural guarantees to ensure the right to defend their position in court. Thus, art. 4 of the Civil Procedure Code of Ukraine (Law No. 1618-IV, 2004) stipulates that each person has the right to apply to the court independently or state authority may apply to the court on behalf of a person. The waiver of the right to go to court for protection is invalid. All of the above fully applies to people with disabilities.

The national legislator has also enshrined in regulations some definitions relating to the issue under study.

In particular, under the state building norms of Ukraine, accessibility for people with disabilities - providing women and men with disabilities access on an equal footing with others to the physical environment, transport, information and communication, information and communication technologies and systems, services, as in urban, and in rural areas (paragraph 3.8) (Ministry of Regional Development of Ukraine, 2018). Analyzing the above definition, we consider it necessary to express the author's position on the inappropriateness of detail in the definition of women and men, as children were left out of consideration in this case. In addition, in our opinion, this definition does not give an idea of the content of the category, which it denotes, because accessibility is explained through access. In all other respects, the provision is almost identical to the first part of Article 9 of the Convention.

It should also be noted, about the understanding of accessibility by civil society, which takes care of the problems of people with disabilities. In particular, in a broad sense, accessibility is the removal of existing barriers that prevent a person from exercising his or her right to education, employment, leisure, health care, information, etc. Therefore, the assessment of the state of accessibility requires a comprehensive and universal approach. Accessibility is an indication of the extent to which a "product" or service can be used by a person with a disability as effectively as it is used by a person without a disability (Azin, Baida, Grybalsky, \& Krasyukova-Enns, 2013).

Ways to ensure the accessibility of people with disabilities to facilities and services:

Providing universal design;

Universal Design is the basis for the design of the environment, public buildings, and structures, 


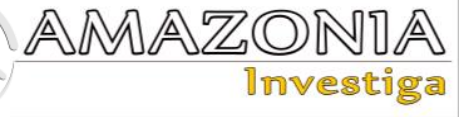

public vehicles, things, technologies, any information publications, or the way information and communication are presented in such a way that they can be used by the broadest sections of the population, regardless of their possible functional limitations. Universal Design is often used in the sense of "design for all", or "inclusive design". This is not a design style, but a focus on any type of design under the lens of social harmony. That is the process that begins with the designer's awareness of their own social responsibility for taking into account the changes that people experience throughout life, for its focus on the diversity of needs, capabilities, and experiences of users.

Thus, universal design is a strategy that aims to ensure that the design and components of any environment, product, communication, information technology, or service are equally accessible and understandable to all and meet the requirements of sharing, as independent and natural as possible, preferably without the need to adapt or apply specialized solutions.

This strategy provides a transition to a usercentered design based on a holistic approach aimed at meeting the needs of all people, taking into account possible changes in their abilities throughout life.

Providing a reasonable device.

At the same time, a smart device is an individual architectural and planning solution that provides LMG with a minimum standard of accessibility in terms of reconstruction, restoration, overhaul, and technical re-equipment of existing residential buildings and public buildings and structures. Auxiliary technical means and mechanisms (ramps, lifting devices, mechanisms, portable ramps) can be a reasonable device (paragraph 3.36). At the same time, universal design is a design of buildings and structures that is most suitable for use by all categories of the population without the need for additional adaptation. The universal design does not preclude the use of assistive devices for specific groups of persons with disabilities (paragraph 3.49) (Ministry of Regional Development of Ukraine, 2018).

According to the Law of Ukraine "On Education" (Law No. 145-VIII, 2017) reasonable accommodation is the introduction if necessary in a particular case, the necessary modifications and adaptations to ensure the implementation of persons with special educational needs of the constitutional right to education on an equal footing with others (paragraph 24 of Article 1); universal design in the field of education - design of subjects, environment, educational programs, and services that ensures their maximum suitability for use by all persons without the necessary adaptation or special design (paragraph 28 of the first part of Article 1).

Among the important guarantees of the rights of persons with disabilities, the right to play sports is also important. And although the sports infrastructure in our country is not properly adapted to the needs of people with disabilities, the results of this year's Paralympic Games, where Ukrainians took sixth place overall, show that our country has significant potential in Paralympic sports. Therefore, domestic legislation and infrastructure must be brought into line with European standards as soon as possible (Tkalych, Davydova, \& Tolmachevska, 2020; Kharytonov, Kharytonova, Kostruba, Tkalych, M., \& Tolmachevska, 2020; Bolokan, Samoylenko, Tkalych, Panchenko, \& Dmytriv, 2021; Kolomoiets, Tkalych, Melnyk, Panchenko, \& Tolmachevska, 2021; Kharytonov, Kharytonova, Tkalych, Bolokan, Samilo, \& Tolmachevska, 2021).

\section{Conclusions}

In summary, the accessibility of facilities and services for people with disabilities is the property of the facilities and services, which allows people in this category to use them freely without any barriers, including through adaptation or special design.

Thus, the essence of the right of people with disabilities to access facilities and services is the ability of persons of this category to enjoy all the rights guaranteed to them without any restrictions due to the barrier of the environment and services.

The nature of the right of persons with disabilities to access facilities and services is the legally guaranteed possibility of these persons to freely use all facilities and services without any barriers, including through the adaptation of the latter or their special design.

This right is important not only for people with disabilities but also for the vast majority of people, such as the elderly, pregnant women, people with prams or suitcases, etc. (low mobility groups). Therefore, each of us in our lives in certain circumstances needs to ensure the availability of facilities and services. 
However, the level of barriers to the environment and services for people with disabilities and other low-mobility groups in Ukraine remains extremely high, and the necessary legislative and practical measures must be taken to remedy the negative situation with accessibility. A significant part of Ukrainian citizens with disabilities are not able to exercise their rights precisely because of inadequate accessibility.

Finally, creating an inclusive society requires a deeper understanding of existing barriers, the eradication of utopian strategies, and the provision of practical mechanisms for political decision-making. An inclusive society is based on fundamental human values, that "all human beings are born free and equal in dignity and rights. They are endowed with reason and conscience and must act concerning each other in a spirit of brotherhood."

\section{Bibliographic references}

Azin, V.O., Baida, L. Yu., Grybalsky, Ya. V., \& Krasyukova-Enns, O.V. (2013). Accessibility and universal design. Kyiv: Istina. ISBN 978966-97230-3-1. Recovered from https://ud.org.ua/images/pdf/Dostupnist_ta_ universalniy_dizayn.pdf

Bolokan, I., Samoylenko, G., Tkalych, M., Panchenko, B., \& Dmytriv, V. (2021). Sanciones en el deporte La relación entre la regulación legal y local (Sanctions in Sport: The Relationship Between Legal and Local Regulation). Retos, Vol 42, pp. 662-672. Recovered from https://doi.org/10.47197/retos.v42i0.88681

Broderick, A. (2015). The Long and Winding Road to Equality and Inclusion for Persons with Disabilities: The United Nations Convention on the Rights of Persons with Disabilities. Intersentia. Maastricht. ISBN 978-1-78068-358-4.

DOI: 10.26481/dis.20151120ab, Recovered from https://cris.maastrichtuniversity.nl/ws/portalf iles/portal/1699051/guid-17dc193e-9ce940b4-8aeb-9b3756a275ae-ASSET1.0.pdf

Broderick, A., \& Ferri, D. (2019). International and European Disability Law and Policy: Text, Cases and Materials (Law in Context). Cambridge: Cambridge University Press. doi: 10.1017/9781108289450

Broderick, A., \& Waddington, L. (2016). Disability law and reasonable accommodation beyond employment A legal analysis of the situation in EU Member States. Intersentia. Maastricht. DOI:10.2838/15305. Recovered from https://www.researchgate.net/publication/30
2984788_Disability_law_and_reasonable_ac commodation_beyond_employment_A_lega 1_analysis_of_the_situation_in_EU_Member States

Campbell Black, H. (1968). Black's Law Dictionary. St. Paul, Minn.: West 1. Publishing Co. Recovered from https://heimatundrecht.de/sites/default/files/ dokumente/Black'sLaw4th.pdf

Kharytonov, E., Kharytonova, O., Kostruba, A., Tkalych, M., \& Tolmachevska, Y. (2020). Las peculiaridades de la regulación legal y no legal de las relaciones sociales en el ámbito del deporte (To the Peculiarities of Legal and Non-Legal Regulation of Social Relations in the Field of Sport). Retos, Vol 41, pp. 131$137 . \quad$ Recovered from https://doi.org/10.47197/retos.v0i41.84178

Kharytonov, E., Kharytonova, O., Tkalych, M., Bolokan, I., Samilo, H., \& Tolmachevska, Y. (2021). Intellectual property law in the field of sports: specifics of manifestations and features of legal regulation. Cuestiones Políticas, 39(69), pp. 530-546. Recovered from

https://doi.org/10.46398/cuestpol.3969.33

Kolomoiets, T., Tkalych, M., Melnyk, P., Panchenko, B., \& Tolmachevska, Y. (2021). Lucha contra la corrupción en el deporte: aspecto legal (Combating Corruption in Sport: Legal Aspect). Retos, Vol 41, pp. 746$755 . \quad$ Recovered from https://doi.org/10.47197/retos.v41i0.86975

Kondratenko, V. N. (2019). Administrative and legal means of ensuring the rights and freedoms of persons with disabilities. (Doctoral thesis). Kharkiv National University of Internal Affairs, Kharkiv. Recovered from http://dspace.univd.edu.ua/xmlui/handle/123 456789/6693

Krahn, G. L., Walker, D.K., \& Correa-DeAraujo, R. (2015). Persons with Disabilities as an Unrecognized Health Disparity Population. In: American Journal of Public Health, Num 105, pp. 198-206. Recovered from

https://www.ncbi.nlm.nih.gov/pmc/articles/P MC4355692/

Larson, D. A. (2014). Article Access to Justice for Persons with Disabilities: An Emerging Strateg. Laws, Num 3, pp. 220-238. DOI:10.3390/laws3020220. Recovered from https://www.mdpi.com/2075$471 \mathrm{X} / 3 / 2 / 220 /$ pdf.

Law No. 145-VIII, On Education. Bulletin of the Verkhovna Rada of Ukraine, Kyiv, Ukraine, September 5, 2017. Recovered from 


\section{AMAZONZ令 \\ 1กvestiำ}

https://zakon.rada.gov.ua/laws/show/214519\#Text

Law No. 1618-IV, Civil Procedure Code of Ukraine. Bulletin of the Verkhovna Rada of Ukraine, Kyiv, Ukraine, March 18, 2004. Recovered

from https://zakon.rada.gov.ua/laws/show/161815\#Text

Law No. 254к/96-BP, Constitution of Ukraine. Bulletin of the Verkhovna Rada of Ukraine, Kyiv, Ukraine, June 28, 1996. Recovered from

https://zakon.rada.gov.ua/laws/show/254\%D 0\%BA/96-\%D0\%B2\%D1\%80\#Text.

Law No. 875-XII, On Fundamentals of Social Protection of Persons with Disabilities in Ukraine. Bulletin of the Verkhovna Rada of Ukraine, Kyiv, Ukraine, March 21, 1991. Recovered from https://zakon.rada.gov.ua/laws/show/87512\#Text

Ministry Of Regional Development of Ukraine. (2018). Inclusiveness of buildings and structures. Substantive provisions. Ukrarchbudinform. Kyiv. Recovered from https://zniiep.com.ua/INKLYUZIVNIST_B UDIVEL_I_SPORUD_DBN.doc
Ovcharenko, O. M. (2008). Accessibility of justice and guarantees of its realization. Kharkiv: Pravo. Recovered from http://library.nlu.edu.ua/POLN_TEXT/KNI GI/MonoOvcharenko.pdf.

Tkalych, M., Davydova, I., \& Tolmachevska, Y. (2020). Current State and Prospects of Development of the Sports System of Ukraine: Legal Aspects. Retos, Vol 38, pp. 385-389. Recovered from https://recyt.fecyt.es/index.php/retos/article/ view/76997

United Nations. (2006). convention on the rights of persons with Disabilities. Recovered from https://www.un.org/development/desa/disabi lities/convention-on-the-rights-of-personswith-disabilities.html

United Nations. (2010). Committee on the Rights of Persons with Disabilities Day of General Discussion on "Accessibility". Recovered from

http://www.ohchr.org/EN/HRBodies/CRPD/ Pages/DGD7102010.aspx Committee on the Rights of Persons with Disabilities Day of General Discussion on "Accessibility", 7 October 2010 